\title{
Using homeopathica drugs combination at peripartal phase in preventing bovine subclinical mastitis
}

\author{
Agatha Winny Sanjaya ${ }^{*}$, I Wayan Teguh Wibawan ${ }^{*}$, Mirnawati Sudarwanto ${ }^{*}$, Setyo Widodo ${ }^{*}$, Heinrich Enbergs ${ }^{f}$
}

\begin{abstract}
Abstrak
Tigapuluh tiga ekor sapi perah penderita mastitis subklinis dikelompokkan dalam grup A (10 ekor), grup B (12 ekor) dan grup C (11 ekor). Sapi diobati dengan homeopatika dalam bentuk kombinasi dan plasebo, pada minggu ke-4 dan 3 sebelum partus (a.p) dan setiap minggu selama 4 kali berturut-turut setelah partus (p.p).Grup A diobati dengan Coenzyme comp ${ }^{\circledR}$ (minggu ke-4 dan 3 a.p), Lachesis comp ${ }^{\circledR}$ dan Traumeel ${ }^{\circledR}$ (minggu ke-1 dan 2 p.p), Coenzyme comp ${ }^{\circledR}$ dan Carduus comp ${ }^{\circledR}$ (minggu ke-3 dan 4 p.p). Grup B diobati dengan Traumeel ${ }^{\circledR}$ dan Mucosa comp ${ }^{\circledR}$ (minggu ke-4 dan 3 a.p), Lachesis comp ${ }^{\circledR}$ dan Traumeel ${ }^{\circledR}$ (minggu ke-1 dan 2 p.p), Coenzyme comp ${ }^{\circledR}$ dan Carduus comp ${ }^{\circledR}$ (minggu ke-3 dan 4 p.p). Grup C adalah plasebo. Kasus mastitis subklinis bagi grup A dan C sangat bervariasi sedangkan grup B memperlihatkan insidensi sebesar $33.3 \%$ dan bertahan konstan sampai akhir pengamatan. Kenaikan jumlah sel somatik susu dari grup A dan B satu minggu setelah terapi terakhir selama 2 minggu (minggu ke-5 - 7 p.p) memperlihatkan adanya suatu respon yang nyata terhadap terapi homeopathy. Menjelang kelahiran terjadi peningkatan haptoglobin (Hp) bagi grup B $0.857 \mathrm{mg} / \mathrm{ml}$ dan grup A juga plasebo $1.438 \mathrm{mg} / \mathrm{ml} \mathrm{serta} 1.422 \mathrm{mg} / \mathrm{ml}$. Setelah partus sampai akhir pengamatan, grup B memperlihatkan penurunan Hp mencapai $0.074 \mathrm{mg} / \mathrm{ml}$. Kadar Hp darah grup A menurun secara perlahan, kadar terendah dicapai $0.176 \mathrm{mg} / \mathrm{ml}$. Pengamatan produksi susu selama 5 bulan (dari bulan ke-3 sampai ke-7) dalam masa laktasi normal menunjukkan adanya peningkatan 14.5\% bagi grup B dan $4.98 \%$ bagi grup A. (Med J Indones 2004; 13: 221-6)
\end{abstract}

\begin{abstract}
A total of 33 dairy lactating cows suffering from subclinical mastitis were classified into group A (10 cows), group B (12 cows) and group $C$ (11 cows). They were treated with the combination of homeopathic drugs and placebo, applied at the $4^{\text {th }}$ and $3^{\text {rd }}$ week antepartum (a.p), and continuing every week postpartum (p.p), for four times. Group A received Coenzyme comp ${ }^{\circledR}$ (in the $4^{\text {th }}$ and $3^{\text {rd }}$ week a.p), Lachesis comp ${ }^{\circledR}$ combined with Traumeel ${ }^{\circledR}\left(1^{\text {st }}\right.$ and $2^{\text {nd }}$ week p.p) and Coenzyme comp ${ }^{\circledR}$ combined with Carduus comp ${ }^{\circledR}\left(3^{\text {rd }}\right.$ and $4^{\text {th }}$ week p.p). Group B received Traumee ${ }^{\circledR}+$ Mucosa comp ${ }^{\circledR}\left(4^{\text {th }}\right.$ and $3^{\text {rd }}$ week a.p $)$, Lachesis comp ${ }^{\circledR}+$ Traumeel $^{\circledR}\left(1^{\text {st }}\right.$ and $2^{\text {nd }}$ week p.p) and Coenzyme comp ${ }^{\circledR}+$ Carduus comp ${ }^{\circledR}\left(3^{\text {rd }}\right.$ and $4^{\text {th }}$ week p.p) and group $C$ as a placebo. The incidence of subclinical mastitis in group $A$ and $C$ appeared irregular. In contrast, group B showed a constant percentage (33.3\%). Group A and B showed significant response to the homeopathic drugs, expressed as an increasing of the somatic cell count value. At peripartal phase, haptoglobin increased in group B $0.80 \mathrm{mg} / \mathrm{ml}$ and group A as well as placebo $1.40 \mathrm{mg} / \mathrm{ml}$. After calving, group B expressed a constant value $(0.05$ $\mathrm{mg} / \mathrm{ml}$ ), while group $A$ and placebo rose significantly. The milk yield in normal lactation period (the $3^{\text {rd }}-7^{\text {th }}$ month) increased significantly, with an increasing $14.1 \%$ for group B and 4.9\% A respectively. (Med J Indones 2004; 13: 221-6)
\end{abstract}

Keywords: Homeopathy, Homeopathic combination, Subclinical Mastitis, Peripartal Phase

Subclinical mastitis has remained the most economically important problem in dairy cattle in Indonesia with high prevalence ranging from 85 to $90 \%{ }^{1}$ Subclinical mastitis is one of the main problems in dairy industry, involving financial losses incurred by decreasing milk, medical expenses, increased number of culled animals, wasted milk of treated animals. ${ }^{2}$

\footnotetext{
* Faculty of Veterinary Medicine, Bogor Agricultural University, Bogor, Indonesia

${ }^{f}$ Institut für Anatomie, Physiologie und Hygiene derHaustiere der Univ. Bonn, Bonn, Germany
}

Homeopathy has increasingly been consi-dered as a possible solution for animal health problems in recent years. Peripartal period (about 4 weeks before and after birth) is considered as a critical point and imbalance physiological condition of the dairy cows due to the sudden changes or switch over of many processes, including hormonal, metabolic, stress and cytologic performance. Especially during the early lactation stage, problems may arise in maintaining the cow in a physiological balance. This might influence the whole system of the defense mechanism. A negative balance of energy is caused by the following ${ }^{3}$ : 
(1) exhaustion of reserves of carbohydrates

(2) conversion of the body's protein into sugars

(3) mobilisation of lipid depots and decompo-sition of the lipids to produce energy with a risk of a fatty liver

(4) increase of so called aceton-bodies.

Disturbance of energy balance is not only a consequence of one system, but it also involes complex disturbances of other systems. The use of a homeopathic combination drugs may achieve a broad spectrum of drug's efficacy.

The general objectives of this study are:

1) to study the most effective combination of the homeopathic drugs in the prevention and therapy of subclinical mastitis.

2) to study the effect of the homeopathic drugs in enhancing milk production and quality.

3) to study the influence of homeopathic drugs to the blood profile of subclinical mastitis-treated cows.

\section{METHODS}

Thirty three subclinical mastitis lactating Holstein Friesian cows were selected into 3 group at one research herd. Ten cows were treated with code A, 12 cows code B and 11 cows code $\mathrm{C}$. The study was done in a blinded form. The experiment was carried out in Taurus Dairy Farm, located in Cicurug, Sukabumi, Indonesia. Cows were in pregnant condition of 3-6 months, continued until 8 weeks post partum. The dairy cows were between 2 - 7 years of age.

\section{Determination of health status of cows concerning subclinical mastitis}

Animals are screened for subclinical mastitis using IPB-1 and somatic cell count according to Breed method.

\section{a. IPB-1 Test}

Milk sample in equal volume with IPB-1 reagent are mixed on a test shell and rotated for 15 seconds. The positive reaction is shown by coagulation of the test suspension.. This reaction is classified into 3 categories:

$1+:$ a light coagulation

$2+:$ a distinct clotting (clear coagulation)

$3+:$ a very clear and strong coagulation in the form of a gelatinous mass.

In case of a negative result it only shows a homogenous aspect.

\section{b. Somatic cell count}

A volume of $0,01 \mathrm{ml}$ of milk is smeared in one square $\mathrm{cm}$ on an object glass and stained with Methylen Blue Loeffler. The somatic cell is counted under a light microscope 100x10 (Breed method). Milk with a somatic cell count (SCC) more than $400,000 / \mathrm{ml}$ is classified as suffering from subclinical mastitis. When the animals show negative reactions with IPB-1, and have SCC below $400,000 / \mathrm{ml}$, they are categorised as healthy.

\section{Blood Analysis}

Serum is used for haptoglobin analysis (Elisa) and is collected after the cows have been milked.

\section{Milk Production}

The data about milk yield were collected from a monthly annual recording.

\section{Research Design}

Cows suffering from subclinical mastitis are divided into 3 groups (A, B and C). The homeopathic drugs were blinded before the application $(5 \mathrm{ml}$, subcutan) and during the research project.

Group A: given homeopathic drugs with Code A

Group B: given homeopathic drugs with Code B

Group C: given homeopathic drugs with Code $\mathrm{C}$

After completing the evaluation of the collected data, the codification was solved. Table 1 and 2 show the solved application schedule.

Table 1. Combination of homeopathic drugs used in the treatments

\begin{tabular}{|c|c|c|c|c|c|c|}
\hline \multirow{2}{*}{ Group } & \multicolumn{2}{|c|}{$\begin{array}{l}\text { Applied at } \\
\text { ante partum }\end{array}$} & \multicolumn{4}{|c|}{ Applied at post partum } \\
\hline & -4 & -3 & 1 & 2 & 3 & \\
\hline A & \multicolumn{2}{|c|}{$\begin{array}{l}\text { 2x5ml Coenzy- } \\
\text { me comp }{ }^{\mathbb{*} *}\end{array}$} & \multicolumn{4}{|c|}{ 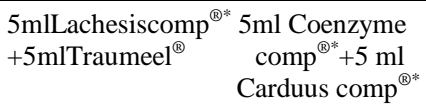 } \\
\hline B & \multicolumn{2}{|c|}{$\begin{array}{l}\text { 5mlTraumeel } \\
+5 \mathrm{mlMucosa} \\
\text { comp }^{\circledR *}\end{array}$} & Idem & & \multicolumn{2}{|c|}{ idem } \\
\hline $\mathrm{C}$ & \multicolumn{2}{|c|}{ Placebo } & Place & & \multicolumn{2}{|c|}{ Placebo } \\
\hline
\end{tabular}

-4 and -3 means the $4^{\text {th }}$ and $3^{\text {rd }}$ week ante partus

$1,2,3$ and 4 are $1^{\text {st }}$ until $4^{\text {th }}$ week post partus

${ }^{\circledR *}$ Fa. HEEL Baden-Baden, Germany

Milk yield monitored monthly for 5 months and the milk quality was monitored twice a week at the $3^{\text {rd }}$ week until the $7^{\text {th }}$ week p.p. The blood analysis was 
done twice, before partus and during the research (once every 2 weeks), after partus 4 times. The efficacy of homeopathic drugs in controlling subclinical mastitis is deter-mined by evaluating the following parameters: IPB-1; somatic cell counts; and haptoglobin.

Table 2. Application schedule of respective homeopathic combination (A, B and C) and time of milk and blood sampling

\begin{tabular}{|c|c|c|c|c|c|c|c|c|c|c|}
\hline \multirow{2}{*}{ Activity } & \multicolumn{10}{|c|}{ Observation (week) } \\
\hline & -4 & -3 & 1 & 2 & 3 & 4 & 5 & 6 & 7 & 8 \\
\hline Therapy & $\mathrm{t}$ & $\mathrm{t}$ & $\mathrm{t}$ & $\mathrm{t}$ & $\mathrm{t}$ & $\mathrm{t}$ & & & & \\
\hline Milk & & & & & $\mathrm{m}$ & $\mathrm{m}$ & $\mathrm{m}$ & $\mathrm{m}$ & $\mathrm{m}$ & $\mathrm{m}$ \\
\hline Blood & $\mathrm{b}$ & $\mathrm{b}$ & $\mathrm{b}$ & & $\mathrm{b}$ & & $\mathrm{b}$ & & $\mathrm{b}$ & \\
\hline $\begin{aligned} \mathrm{t} & =\text { thera } \\
\mathrm{m} & =\text { milk } \\
\mathrm{b} & =\text { blood }\end{aligned}$ & $\begin{array}{l}\text { with } \\
\text { nple } \\
\text { impl }\end{array}$ & $\begin{array}{r}\mathrm{p} \\
\text { res } \\
\text { are } \mathrm{t}\end{array}$ & $\begin{array}{l}\text { tus } \\
\text { ecti } \\
\text { ken } \\
\text { ake }\end{array}$ & $\begin{array}{l}\text { cor } \\
\text { vice } \\
\text { afte }\end{array}$ & $\begin{array}{l}\text { inat } \\
\text { wee } \\
\text { nilki }\end{array}$ & $\begin{array}{l}\text { on of } \\
\text { at } 1 \\
\text { g be }\end{array}$ & $\begin{array}{l}\text { lom } \\
.00 \\
\text { re } t\end{array}$ & $\begin{array}{l}\text { pat } \\
\text { cloc } \\
\text { atm }\end{array}$ & $c d r$ & \\
\hline
\end{tabular}

\section{RESULTS AND DISCUSSION}

\section{Incidence of Subclinical Mastitis}

The incidence of subclinical mastitis represents the effect of treatments of respective homeo-pathic drug combination. These were observed with the IPB-1 test. The incidence of subclinical mastitis in cows in group B was steady for 5 weeks $(33,3 \%)$ and then it decreased in the last week of observation (Fig.1). On the contrary, irregular frequency of subclinical mastitis cases were observed in cows treated in A as well as in group $\mathrm{C}$ (placebo).

These results indicated that the curative effect of the Mucosa comp. is responsible for the responsive healing of unhealthy tissues, the stimulation of organ dysfunction, and the repair of the damage of mucous tissues. The biologi-cal activity of the Coenzyme comp. is as an intermediate catalysator, a trigger to the intra-cellular respiration, and a modulator of group $B$ depressed the incidence of subclinical mastitis. The homeopathic substance which only be-longed to group B is the Mucosa comp. respiration enzymes. Traumeel has an anti inflammatory effect and activates phagocytosis. In-vitro and in-vivo studies demonstrated that Traumeel modulates the release of oxygen radicals from activated neutrophile granu- locytes and also suppresses inflammatory mediators. ${ }^{4}$ The main biological activity of Lachesis is to stimulate the mitogenesis of $\mathrm{T}$ and $\mathrm{B}$ lymphocytes.

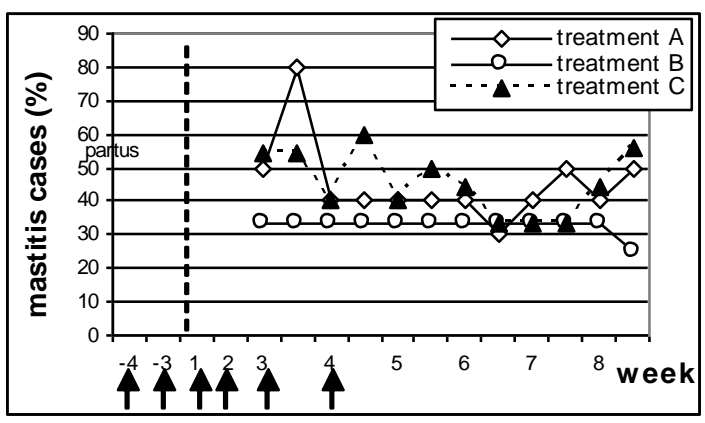

Figure 1. The incidence of subclinical mastitis by cows treated with respective homeopathic drug combinations determined with IPB-1 test

treatment A : Coenzymecomp, Lachesiscomp. Traumeel, Carduuscomp $(\mathrm{n}=10)$

treatment B : Mucosacomp., Traumeel, Lachesiscomp, Carduus comp, Coenzyme comp. $(\mathrm{n}=12)$

treatment $\mathrm{C}$ : placebo $(\mathrm{n}=11) \mathrm{t}$

\section{Somatic Cell Count}

The appearance of somatic cells in milk shows that there is a bacterial infection. Therefore, $98 \%$ of blood leukocytes that enter the milk will destroy the bacteria causing the infection. Some natural increase of SCC in milk could be expected as lactation progress. ${ }^{5}$

All cows in respective groups were observed periodically for incidence of subclinical mastitis by somatic cell counts (SCC). The results are presented in Figure 2. One week after the last treatment of the group A or B, showed a significant increase in SCC.

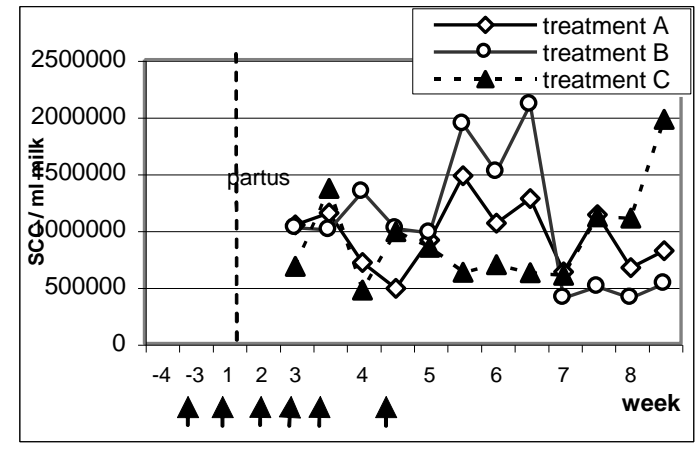

Figure 2 The effect of homeopathic treatments to the profile of somatic cell counts 
The increase of SCC is based on the increase of leukocytes in blood, as a conse-quence of a physiological stimulation. ${ }^{6}$ This might be caused by the effect of Lachesis comp. and Traumeel treatments for group A and B. Lachesis is well known as an immunostimulantia that stimulates the mitoge-nesis of lymphocytes and increase the phagocytosis activities. ${ }^{7}$ The normal value of SCC for the animals in group A and $\mathrm{B}$ was reached in 3 weeks after treatment. Contrary to this, group $\mathrm{C}$, which was treated with a placebo, showed a tendency of a steady increasing value of SCC over the starting level.

\section{Haptoglobin}

Haptoglobin concentration of respective groups of treated animals is presented in Figure 3. All groups showed a similar profile, the increase of haptoglobin concentration was observed at the parturition (peripartal phase) and greatly increased to $0.80 \mathrm{mg} / \mathrm{ml}$ for group B treated cows, and $1.40 \mathrm{mg} / \mathrm{ml}$ for group A as well as with the placebo at approximately a week after partus. Interestingly, the cows treated with combination B expressed a constant value (0.05 $\mathrm{mg} / \mathrm{ml}) 3$ weeks after birth, while the haptoglobin concentration rose by cows treated with combination A as well as with the placebo (Figure 3 ).

The similar results due to the haptoglobin concentration and peripartum phase by cows have also been reported by Fürll et al., where the increase of haptoglobin was deter-mined one week after partus $(0.73 \mathrm{mg} / \mathrm{ml})$ with a constant value of $0.04 \mathrm{mg} / \mathrm{ml}$. These results are in a good agreement with the previous results, ${ }^{8}$ which showed that the concentration of haptoglobin increased to $1.0 \mathrm{mg} / \mathrm{ml}$ at the peripartum phase.

The homeopathic drugs of combination B seemed to have a good effect in the controlling of stress (inflammation) at the parturition phase. This is indicated by the lower concen-tration of haptoglobin and a constant value of haptoglobin in 3 weeks after partus, compared to other groups. The increase of haptoglobin in blood could be induced by acute phase response such as inflammation. The tendency of increasing haptoglobin is observed by cows treated with combination $\mathrm{A}$ as well as $\mathrm{C}$.
The haptoglobin induction at peripartal phase is associated with fatty liver develop-ment, because these lipid-related changes are prerequisites for fatty liver development. Fatty liver particularly occurs in the peripartum period and is proposed to be triggered by an imbalance of metabolic stress. The homeopathic drugs of group B seemed to have a good effect in the controlling of stress (inflammation) at the parturition phase. This is indicated by the lower concentration of haptoglobin and a constant value of haptoglobin 3 weeks after partus, compared to other groups. The increase of haptoglobin in blood could be induced by an acute phase response such as inflammation. The tendency of increasing value of haptoglobin is observed by cows treated with combination $\mathrm{A}$ as well as $\mathrm{C}$. This indicated that the main causal agents of subclinical mastitis were not eliminated by this treatments.

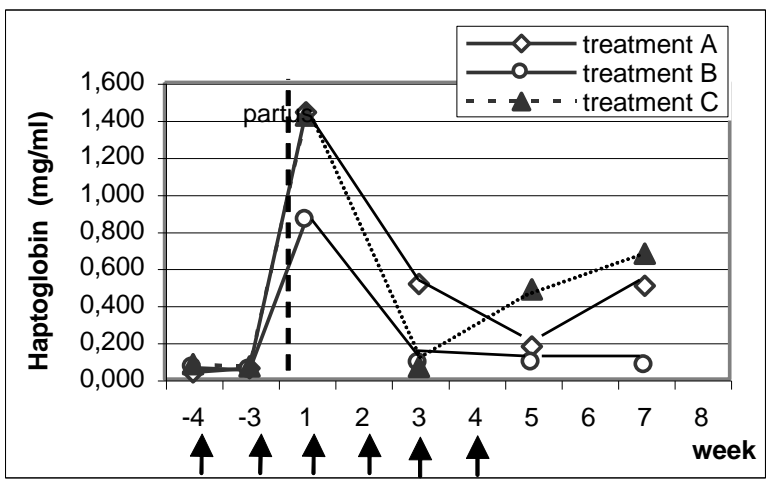

Figure 3. Haptoglobin profile of treated subclinical mastitis cows

\section{Milk Yield}

The effects of treatments to the milk yield were observed by comparing the five-month milk production for respective groups before and after treatments. Milk yield of cows increased significantly after homeopathic drug treatments of group A (4.9\%) and B (14.1\%) with the cows treated with a placebo (Figure 4 ).

The treatments showed that the milk yield of group B treated cows is relatively constant during the observation, compared to the cows treated with drug combination $\mathrm{A}$ or $\mathrm{C}$. This results are relevant with the lowest incidence of subclinical mastitis in cows treated with the drug combination $\mathrm{B}$, and it is relatively constant during the observation. 


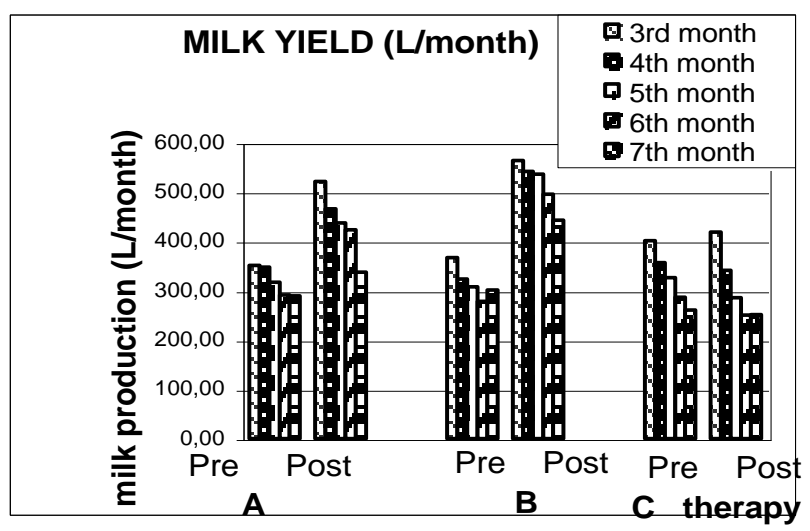

Figure 4. Milk yield observed in normal lactation at the $3^{\text {rd }}-7^{\text {th }}$ month before and after treatment

The results indicated that the homeopathic drug of group B have the most significant stimulating effect on the milk synthesis in the mammary glands.

The difference between homeopathic drug of group B and $\mathrm{A}$ is in the use and the application of Traumeel and Mucosa comp. at antepartus. It seemed that the combination Traumeel and Mucosa comp. has a significant role mostly in the recovery of mucosal epithelial cells, especially in the healing process of mammary mucosal epithelial cells. The recovery of damaged tissue is easily achieved. Damaged tissue is quite susceptible to the infection, and the mammary gland infections are known to reduce milk production. A previous study indicated that there was a significant correlation between udder health and milk production as well as milk qualities. ${ }^{9}$ The critical time for the occurence of subclinical mastitis is the peripartal period, 3 weeks before and 8 weeks after partus. It seemed that the physiological changes of cows during this critical phase is believed to have a very significant role for the incidence of subclinical mastitis. The efficient recovery of the organ systems might be achieved if the emphasis of treatments is given in the stabilizing of the imbalance of metabolic disturbances in this critical period. Basically, the use of homeopathic drugs is not only to eliminate the symptoms of diseases but also the influence of the regulation of cells in maintaining the homeostatic condition. The use of homeopathic drug in combination such as Traumeel, Mucosa comp, Lachesis comp, Coenzyme comp and Carduus comp., offers the possibilities to get synergical potencies and a wide spectrum effects.

Until now, the mechanism and the pharmacokinetics in molecular level of a respective drug used in this combination are not yet fully understood. Homeophatic therapy must be understood as an integrated therapy whose essential properties arise from the relationships between its parts as a set of interacting units, with the relationships among drugs used. This implies that the units have some common properties. These common properties are essential if the units interact among one another or have relationships. In the integrative medicine, the systemic memory mechanism suggests that the wholeness of a system may derive from its capacity not only to interact, but also to interact recurrently and to circulate, mix and accumulate the information and energy within the system. Homeopathy may prove to be a prototypic case of a funda-mental phenomenon worthy of the serious attention of the clinicians and scientists concerned with the challenge of integrating medicine. ${ }^{10}$

The use of homeopathic drugs to control subclinical cases is thought to be useful, because the principal of homeopathic treatments is the earlier the drugs reached the pathologic organs, the better the possibility of the recovery. ${ }^{11}$ In subclinical mastitis cases, the changes are found mostly on the superficial of mucosal epithelial cells of mammary glands. ${ }^{12}$ The Traumeel and Mucosa comp. have a special effect in mucosal cell recovery. This might explain why the Mucosa comp. and Traumeel show a significant effect in depressing subclinical mastitis incidence.

\section{CONCLUSIONS}

The homeopathic drugs of a certain combi-nation can be used to control the incidence of subclinical mastitis. Homeopathic combination B (Mucosa comp, Lachesis comp, Traumeel, Coenzyme comp. and Carduus comp.) have a better efficacy compared to homeopathic drugs of combination A (Coenzyme comp, Traumeel, Lachesis comp and Carduus comp) in supressing the incidence of subclinical mastitis and increasing milk production.

In subclinical mastitis control, the biggest emphasis must be given at the peripartum period as a critical period for the immuno-supression, stress, new infections and meta-bolic imbalance.

Homeopathic therapy must be understood as an integrated therapy whose essential pro-perties arise from the relationships between its parts as a set of interacting units with the relationships among drugs used in the combination. 


\section{Acknowledgements}

We thank to the director of Taurus Dairy Farm, Sukabumi, Indonesia who permit us to use their dairy cows in this research and Fa. HEEL Baden-baden Germany with their homeopathic drugs.

\section{REFERENCES}

1. Sudarwanto M. Mastitis pada Sapi Perah. Seminar Nasional Peternakan dan Veteriner. Bogor, 7-8 Nov 1995.

2. Searcy R., O. Reyes, G. Guajardo. Control of Subclinical bovine mastitis . British Homeopathic Journal 1995; 84: 67-70.

3. Kandefer-Szerszen M, Filar J, Szuster Ciesielska A, Rzeski W. Suppresion of interferon response of bovine leukocytes during clinical and subclinical ketosis in lactating cows. Deutsch tierärztl Wochenschr 1992; 99:440-3.

4. Wagner H. Die Beeinflussung der Phagozytose fähigkeit von Granulozyten durch homöopathischer Arzneipräparate in vitro test und kontrolierte Einfachblind studien. Arzneim Forsch Res 1986; 36:1421-5.
5. Eastridge ML, Hoblet KH. Somatic cells in milk. http://www.inform.umd.edu/EdRes/TopiAgr Env/ndd/milking/somaticcells.html [June 2000] 1992.

6. Sinell HJ, Neuschulz J. Zum vorkommen von Leukozyten in der Milch von gesunden Kühen. Milchwirtsch 1965; 20:344-51.

7. Internationale Gessellschaft für Biologische Medizin e.V. Ordinatio Antihomotoxica et Materia Medica. 6. Auflage. Baden-Baden 1998.

8. Uchida E, Katoh H, Takahashi K. Appearance of haptoglobin in serum from cows at parturition. J Vet Med Sci 1993: 55:893-4.

9. Sudarwanto M. Usaha peningkatan produksi susu melalui program pengendalian mastitis subklinis [Orasi Ilmiah Guru Besar tetap Ilmu Kesehatan Masyarakat Veteriner FKH-IPB], Inst Pertanian Bogor. Bogor: 1999.

10. Schwartz GER, Russek LG. The Plau-sibility of Homeopathy: the Systemic Memory Mechanism. Integrative Med 1998; 2:53-9.

11. Dorenkamp B. Zur homöopathischen Behandlung von Rindermastitiden. Großtier-praxis 2000; 6:26-34.

12. Estuningsih S. Patogenesis Mastitis Subklinis pada Sapi Perah: Pendekatan Histologis Mastitis Subklinis pada Mencit yang diinfeksi Bakteri Streptococcus agalac-tiae Hemaglutinin Positif [Dissertation]. Institut Pertanian Bogor. Bogor: 2001. 